\title{
Management of pindo palm (Syagrus romanzoffiana Arecaceae) in rearing of Coleoptera edible larvae by the Guarani of Northeastern Argentina
}

\author{
Jorge Justino Araujo1, 2, Héctor Alejandro Keller², 3 , Norma Inés Hilgert ${ }^{1,2 *}$
}

\begin{abstract}
Rearing of coleopteran larvae on palm tree stems as a food source is extended among Amerindian groups is as a food source as coleopteran larvae are reared on their stems. Guarani groups settled in the province of Misiones, in northeastern Argentina, consume three species of Dryophthoridae larvae (Metamasius hemipterus, Rhynchophorus palmarum and Rhinostomus barbirostris) which are rear in the stipes of Syagrus romanzoffiana palm. This work deals with the management of the different stages of growth of this palm to promote the development of the three edible larvae species. Field observation suggests a great knowledge of these insects ecology and of the differential characteristics of the palm tree wood anatomical structure throughout its ontogenic development. This constitutes the first record of the use of Metamasius hemipterus as food for the Mbya Guarani people.
\end{abstract}

Keywords: Atlantic Forest; Edible Insects; Metamasius hemipterus; Rhinostomus barbirostris; Rhynchophorus palmarum; Ethnoentomology.

\footnotetext{
1 Instituto de Biología Subtropical, IBS-CONICET. Universidad Nacional de Misiones. Bertoni 85, (3370) Puerto Iguazú, Misiones, Argentina

2 Facultad de Ciencias Forestales, Universidad Nacional de Misiones

${ }^{3}$ Instituto de Botánica del Nordeste, UNNE-CONICET. Sargento Cabral 2131, C.C.:209, (3400) Corrientes, Argentina
} *Corresponding author. E-mail address: JJA (jorgejustinoaraujo@gmail.com), HAK (kellerhector@hotmail.com), NIH
(normahilgert@yahoo.com.ar)

\section{INTRODUCTION}

Insects occupy an important space in the socio-economic development of peoples (Costa Neto 2004). The study of insects as food, as well as the knowledge and management associated with this use are part of the main objectives of
Ethnoentomology (Posey 1987).

The consumption of edible insects has been documented since the Paleolithic (Hernández-Pacheco 1921). This habit is present all over the planet and sometimes species of the same genus are used and raised similarly in all continents (RamosElorduy et al. 2009). Based on the empirical 
knowledge of rural populations there is a record of about 1,800 edible species used by more than 3,000 ethnic groups (RamosElorduy 1997). Occasionally the rearing of edible larvae is promoted in different plant species (Cebolla Badie 2009; Coimbra 1984; Keller 2010; Mitsuhashi 2017). This practice by indigenous groups has been named "cultivation" (Choo et al. 2009; Dufour 1987) or "semi-cultivation" in several papers (Cebolla Badie 2009; Defoliart 1995; Van Itterbeeck and Van Huis, 2012) while others call it "breeding" (Cerda et al. 1999). In some tropical regions this activity has reached commercial importance, where larvae are sold in popular markets and in luxurious restaurants (Delgado et al. 2008; Hanboonsong et al. 2013; PaniaguaZambrana et al. 2014).

Arecaceae is one the most frequently used botanical families for larval rearing. This family is of economic, material and spiritual importance in the daily life of millions of people, providing beverages, food, drugs, households, clothing, fuel and fibers (Dransfield et al. 2008). It includes 200 genera and 2450 species which are distributed in the tropical and subtropical areas of both hemispheres (Borchsenius and Moraes 2006). There are numerous studies about their relationship with human populations: i.e. a review of useful palms around the world (Balick and Beck 1990); their ethnobotany in the Neotropics (Balick 1984); the management of different genera in South America (Balslev 2011; Bernal et al. 2011). In South America, a wide variety of applications are mentioned for the Arecaceae family including: food, medicine, veterinary, cultural, environmental, toxic, fuel, among others (e.g. Baslev 2011; Baslev et al. 2015; Bernal and Galeano 2013; Bernal et al. 2011; Blacutt-Rivero et al. 2016; Gragson 1992; Macia et al. 2011; Paniagua-
Zambrana et al. 2016). Most of these contributions on the use and management of palm trees come from the Amazon rainforest.

The genus Syagrus currently comprises 65 species, 2 subspecies and 14 natural hybrids; it is distributed in the Neotropic, being $S$. romanzoffiana (Cham.) Glassman the species with the southernmost distribution (Noblick 2017). In fact, the natural distribution of this species includes eastern and southern central Brazil, eastern Paraguay, eastern Uruguay and northeastern Argentina, where it is present in the province of Misiones, Corrientes, Entre Ríos, Buenos Aires, Chaco, Santa Fe and Formosa (Cabral and Castro 2007). Common uses of $S$. romanzoffiana documented for different indigenous groups of the Atlantic Forest are food, construction, textiles, medicine and religion (Bonomo and Capeletti 2014; Cárdenas 1989; Dawson and Gancedo 1977; Hurrell et al. 2010; Keller 2014; Pochettino 2015; Reitz 1974; Rosso and Scarpa 2012). This palm provides a great variety of material and is of symbolic use to Guarani people in the province of Misiones, at least 78 different applications have been documented in an ethnobotanical study (Keller 2008).

In the region of this study, the rearing of edible larvae of Coleoptera grown on $S$. romanzoffiana palm stipes and other tree species was reported first by Ambrosetti (1894) and then by Martínez Crovetto (1968), who recorded the development of edible larvae of the curculionid beetle Rhynchophorus palmarum L. These authors mention that this beetle grubs are also called tambú by the indigenous people. In others studies there has been registered pumpkins, mud vessels, hollow logs, palm spathe and hollow reeds as traditional elements used to transport larvae from the forest to domestic 
environments (Cebolla Badie 2009; Keller 2008; Mayntzhusen; 2009; Müller 1989).

According to the most recent ethnobiological research (Cebolla Badie 2009, Keller 2008) these traditional practices continue until the present in Guarani settlements located in the Green Corridor and the Yabotí Biosphere Reserve, in Misiones Province. In these studies, Rhynchophorus palmarum larvae rearing has been documented by the above mentioned authors and Rhinostomus barbirostris (Fabricius) was registered by Cebolla Badie (2009).

The management of palm trees in rural communities, associated with the rearing of edible larvae of Coleoptera, has been dealt with in studies conducted from the ethnobiological perspective in different regions, i.e. in Africa (Dounias 2003; Van Huis 2003), in Asia (Ellen 2006; Hanboonsong et al. 2013; Mercer 1997; Ponzetta and Paoletti 1997; Townsend 1974), in South America (Cerda 2001; Choo et al. 2009; Dufour 1987; Onore 1997).

In the same way, unlike extractivist practices, the management of a resource implies a deeper diachronic knowledge of the components involved in the productive process, especially of the ontogenic phases of the handled species. In this sense, the objective of this work is to provide information related to the use of $S$. romanzoffiana palms for the rearing of larvae of three species of Dryophthoridae among the Guarani of Northeastern Argentina. Special emphasis will be made on management practices at different stages of the palm growth.

\section{Study area}

Misiones is part of the Atlantic Forest of Alto Paraná ecoregion, also known as Selva
Paranaense a semi-deciduous forest (Placci and Di Bitetti 2006) placed in a subtropical climate with maximum temperatures around $40^{\circ} \mathrm{C}$ and minimum temperatures reaching the point of frost and with almost homogeneous rains throughout the year (Crespo 1982).

Archeological evidence of lytic industry confirms Guarani presence in Argentina as early as 900-2000 years BP (Noelli 2004; Schmitz 1991). At present this people represent one of the most numerous original communities in the lowlands of South America (Assis and Garlet 2004).

The current inhabitants of Guarani origin in the province of Misiones are descendants from original dwellers belonging to Mbya and Ava Chiripa communities (Ambrosetti 1894, Müller 1989). At the end of the first decade of the XXI century their population in the province reached 13,006 inhabitants, distributed in approximately 100 villages (INDEC 2015).

In Misiones, some communities are settled in rural or near urban areas distributed in forest remnants along the main roads crossing the region (Crivos et al. 2005; Keller and Prance 2008). Most Guarani settlements maintain much of their traditional subsistence of swidden agriculture, foraging, hunting and occasionally wage labor (Felipim 2001; Jacobsen 2003). In particular, they breed beetles larvae which are developed in downed stipes of palm trees and other tree species (Keller and Prance 2008).

We conducted our study in the Mbya Guarani communities of $Y$ aka pora, Ita piru, Jejy, and Chafariz (Figure 1), all located in the Guarani Department, Misiones, Argentina. The $\mathrm{Y}$ aka pora community ( $26^{\circ} 55^{\prime} 37^{\prime \prime} \mathrm{S}$; $\left.54^{\circ} 14^{\prime} 58^{\prime \prime} \mathrm{W}\right)$ is located about 6 kilometers from provincial route $\mathrm{N}^{\circ} 15$, it is composed by six families and each family is 


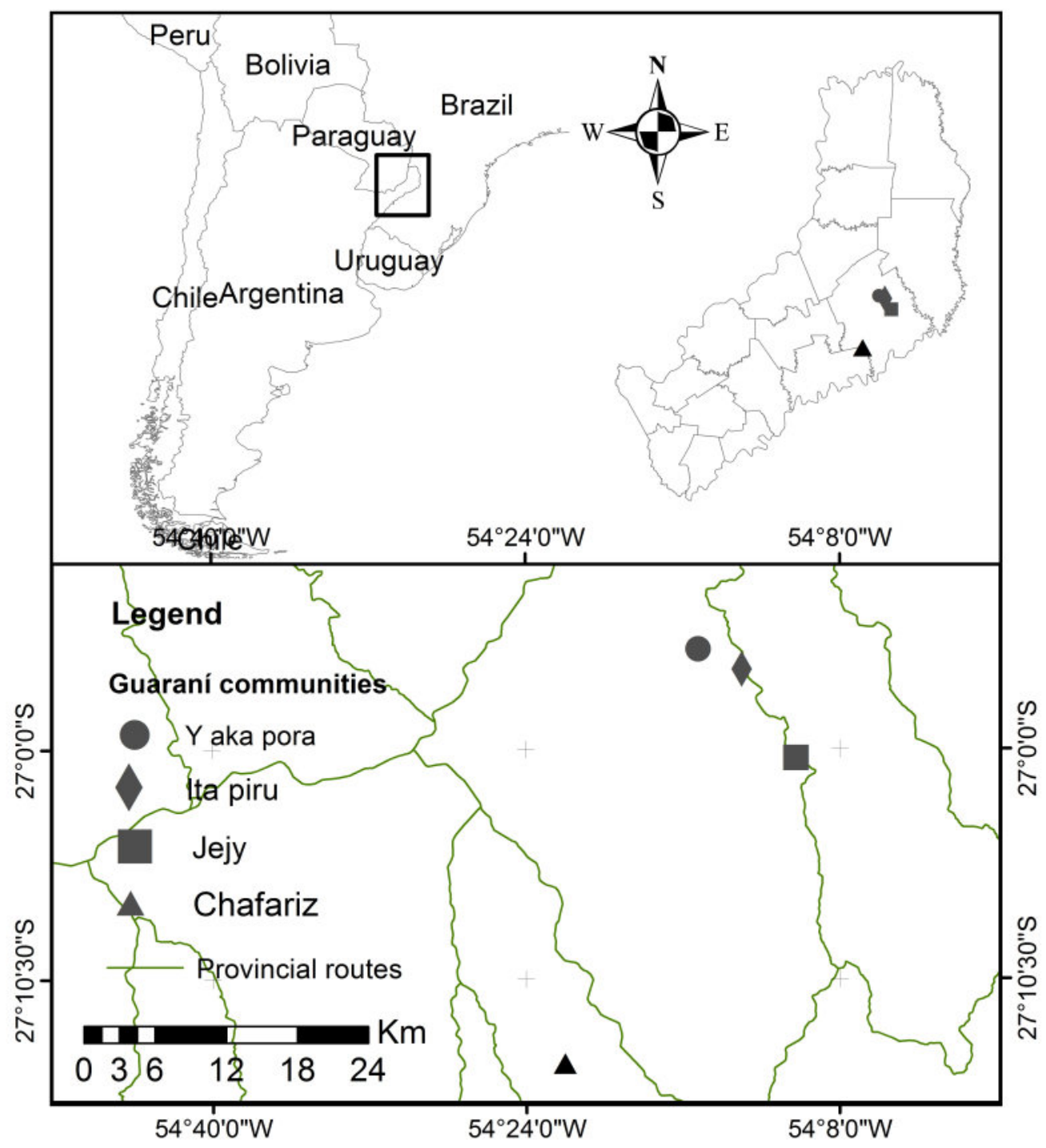

Figure 1. Four Guarani villages visited in this study, in the province of Misiones, Argentina

made up of 4 to 5 members. The village of Ita piru (26 $56^{\prime} 24^{\prime \prime} \mathrm{S}$; $\left.54^{\circ} 12^{\prime} 45^{\prime \prime} \mathrm{W}\right)$ is based on provincial route $\mathrm{N}^{\circ} 15$, has eight families, with similar number of members per family. These two communities are settled within the Reserva de Uso Múltiple (RUMG) belonging to the Universidad Nacional de Misiones (UNaM) and administered by the Facultad de Ciencias Forestales.

The Jejy community $\left(27^{\circ} 00^{\prime} 29^{\prime \prime} \mathrm{S} ; 54^{\circ}\right.$ $09^{\prime} 52^{\prime \prime} \mathrm{W}$ ) also sits on the edge of route $\mathrm{N}^{\circ}$ 15 , is made up of 70 families located within the premises of the Reserva Natural $y$
Cultural Papel Misionero, it currently holds a land title for about 300 hectares. The Chafariz village $\left(27^{\circ} 14^{\prime} 50^{\prime \prime} \mathrm{S} ; 54^{\circ} 22^{\prime} 01^{\prime \prime} \mathrm{W}\right)$ is located about six kilometers from provincial route $\mathrm{N}^{\circ} 13$ on the edge of the homonymous stream, it is constituted by 25 families, the village also has a land title for 106 hectares.

\section{MATERIAL AND METHODS}

The information for this study was collected during 12 short field trips 
conducted between 2015 and 2017. To study the rearing of edible larvae of Coleoptera developed in the $S$. romanzoffiana palm, we used the participant observation, ethnobotanical walks and semi-structured interviews (Albuquerque et al. 2014; Bernard 2000; Guber 2006; Malinowski 1922).

Along the participant observation JJA noticed in detail activities comprising from the palm cut for larval rearing to larvae harvest, as well as, the different management of this palm tree according to the type of insect to be promoted. Thirteen specimens of pindo harvested at different ontogeic stages, according to local users' criteria of differentiation were observed. Finally, informal visits to homes also contributed to understanding the social context, daily way of life and routines of each of the communities visited.

Ethnobotanical walks were made together with 4 local people (one at time) (3 from Ita Piru and 1 from Jejy villages) recognized by members of their communities as experts and leading actors in the activity. During the walks, the basic general aspects of larvae consumption were investigated and the topics to be discussed later in the semistructured interviews were identified. Likewise, the basic lexemes (or semantic domain) used locally in relation to the subject under study were identified.

Finally, 19 semi-structured interviews were conducted in Spanish to adult men, heads of family, aged between 45 and 70 years. This represents about $18 \%$ of families and $22 \%$ of elderly men in these villages. The topics treated in the interviews were: logging season, rearing insect species, time required for larval development in each species, forms of larval consumption, and other uses of the palm tree.

The Syagrus romanzoffiana palm was identified in the field; it is the only species of palm which grows naturally in the studied area. Herbarium samples were collected and compared with material from the IBONE herbarium. To translate the Guarani expressions, Cadogan (1992) and Moliniers and Genes (2003) dictionaries were used.

Samples of adult beetles (Coleoptera: Dryophthoridae) were photographed, collected manually and preserved in $96 \%$ ethyl alcohol. Insect identity was done by specialists (Dr. Lanteri Analia and Dr. Bello Ayr). Samples were deposited in the Museo de La Plata, Facultad de Ciencias Naturales y Museo, UNLP, Argentina.

The authors followed all the requirements and regulations needed for conducting ethnobiological fieldwork in Argentina. Oral informed consent was obtained from each participant involved in this study. Information provided by all participants was kept confidential and was anonymously tracked using an identification number. The required permissions for collection of reference materials were obtained from the Ministerio de Ecología of the Misiones province. No ethical approval was required for this study in Argentina as no participants were subjected to any other treatment than voluntary interviews. The research was carried out following the code of ethics of the American Anthropological Association and the International Society of Ethnobiology Code of Ethics practices in place to promote the production of different species of edible grubs.

\section{RESULTS}

\section{Practices of management the Syagrus romanzoffiana palm to produce different edible coleopteran larvae}

It has been observed in the region that 
the Guarani cut down the pindo palm Syagrus romanzoffiana (Cham.) Glassman, (Arecaceae) and handle the downed stipe to promote the rearing of three species of coleopteran larvae: Metamasius hemipterus, Rhynchophorus palmarum and Rhinostomus barbirotris (Coleoptera: Dryophthoridae). The main management practice consists in the selection of different stages of growth or ontogenic of the palm tree and the subsequent type of post-appendage treatment applied to the stipe. Stage of growth presented are an emic classification recognized by the Guarani and used to define the different age groups of the palm trees. In this context, the Guarani recognize five stages of growth, that comprise from seedlings to adult-senile individuals (Figure 2).

The two first stages are named I pindo oikotaramo (palm tree that begins to exist), II pindo yky (tender palm) seedlings and tender plants of the palm without a visible stipe, neither of them is considered useful for the production of larvae (Figure 2-I and 2-II). As from stage III, each individual receives a different management practice according to its ontogenic stage, and is used for the production of different species of food larvae. The following are the species raised in each stage of the plant and the particular handling in each case.

In stage of growth III the plants are juvenile and immature and are called pindo yky guachu (pre-juvenile palm or literally large tender palm) (Figure 2-III). These specimens are used to produce ycho $i$ or ycho tyr larvae (Figure 2A) of the $M$. hemipterus weevil (Figure 2B), its traditional name means small or tender grubs, and its adult beetles are called tapoarã. In the next stage IV (Figure 2-IV) the pindo pyau (young palm) plants are already in the reproductive stage, they are used to produce ycho pyta larvae (Figure 2C) of the R. palmarum beetle (Figure 2D) (however they also develop larvae of the weevil $R$. barbirostris in the basal part of the stem), its common name means red grubs and refers to the reddish coloration of the larvae oral apparatus, its adult insects are called aramandái (Table 1).

Finally, in stage $\mathrm{V}$ (Figure 2-V) the pindo tuja (old palm) plants are used specifically to produce ycho chĩ (white grubs) larvae (Figure 2E) of $R$. barbirostris weevils (Figure $2 F)$. Pindo tuja plants are specimens that reached reproductive maturity several years before. The name ycho chĩ, or white grubs assigned to the larvae of $R$. barbirostris refers to the white color of it's the oral apparatus. Adults of this species are called chaviju (hairy snout), due to the presence of hair on adult males the faces (Figure 2F). Table 1 shows the different management practices applied at each stage of growth of the palm and for each of the three species of weevils.

Of the 13 specimens of Syagrus romanzoffiana cut down during the study campaigns, three correspond to growth stage III, eight to stage IV and two to stage $\mathrm{V}$. The whole process constitutes an integral activity, cutting palm trees to produce certain types of grubs involves harvest the heart of the palm or pindo ruã, since it is a food resource that can be consumed in situ or lead to domestic areas, picking in many cases also its fruits and occasionally extracting leaves for dwellings, or fibers for clothes. In general terms, the management for the production of edible insect larva in the pindo palm includes the initial removal of lianas and small trees that surround the chosen palm to determine the direction of the fall towards an obstacle free area. Once felled, the surface is either left intact or wedge-shaped transverse incisions are made along the stipe from the base to the 
apex. The opening of these incisions depends on the individual stage of growth and the species of larvae to be produced. In this context, the tools used to handle the palm are axes and machetes.

To obtain the best larvae production per plant, it is necessary to cut it down during the moon phase jachy ray (new moon). According to some interlocutors to obtain the best productions by felled individual, it is necessary to have some rain a few days before the turning and during the larval development. The most favorable time to cut down these plants is from September to March, spring and summer respectively.

The felled palm is visited weekly to monitor larval development. Once the optimum time has elapsed and the presence of suitable larvae in size and quantity for harvesting has been diagnosed, the stem segments are opened longitudinally and edible larvae are collected monthly in a harvesting day.

As for task division in this activity: 1) palm cutting is practiced mainly by adult and young men, 2) the harvest is carried out by individuals of both sexes. The activity is described as follows: "ja a jaity pindo, ja jaga jovái ychorã omboa ñamboguái, ja mbo i pindo ruã jaru anguã ñande rope jauva" (we will cut the pindo down, make cuts on both sides to produce larvae, remove the heart and bring it home to eat).

\section{Rearing of the larvae}

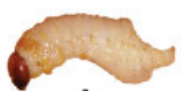

A

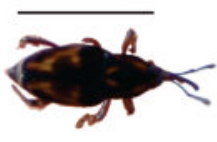

B

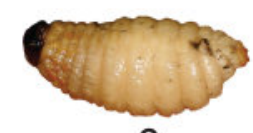

C

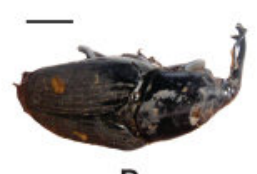

D
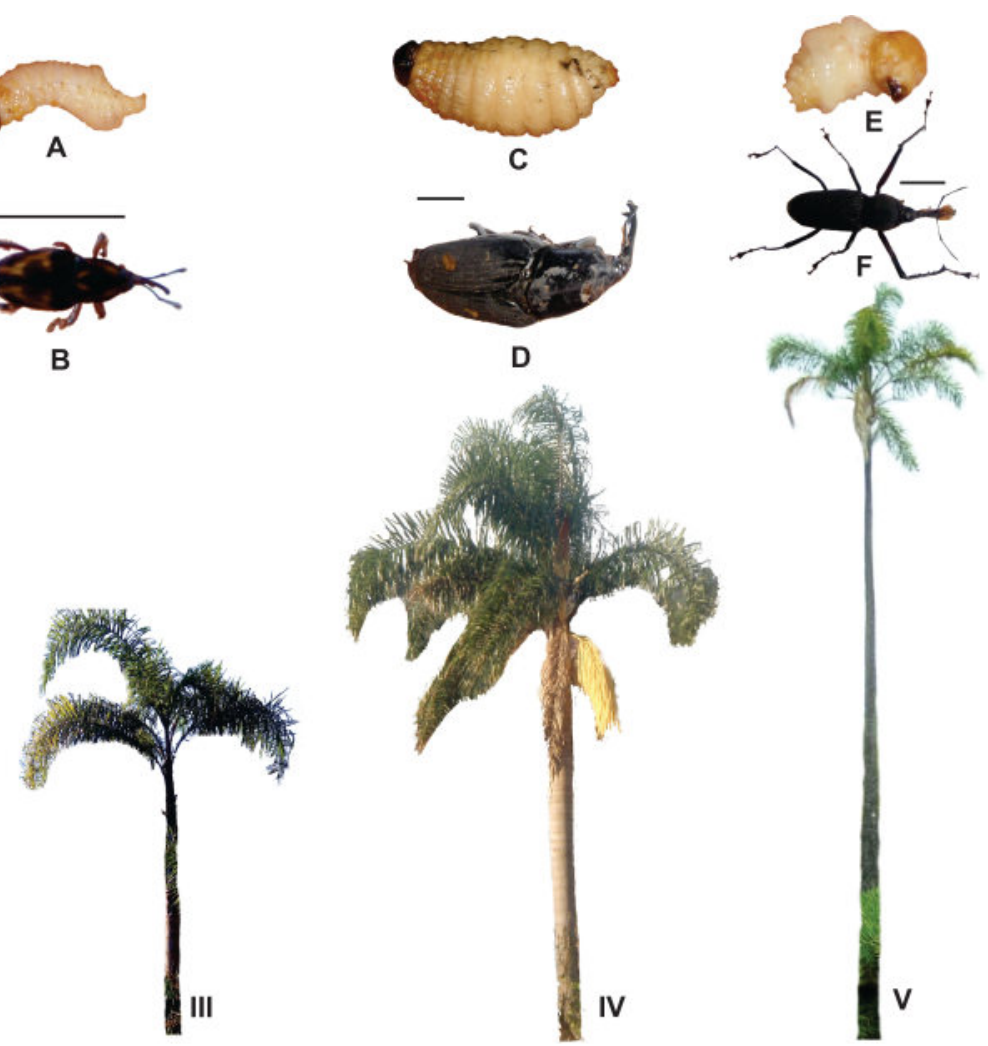

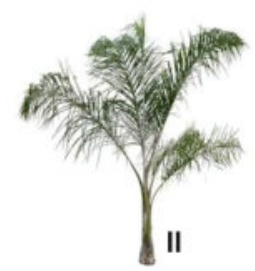

Figure 2. I-V: Palm tree Syagrus romanzoffiana in its five stages of growth according to the local classification. A and B: larva and adult insect of Metamasius hemipterus beetle produced at stage III (scale-1 cm). C and D: larva and adult insect of Rhynchophorus palmarum weevil obtained in stage IV (scale-1 cm). E and F: larva and adult insect of Rhinostomus barbirostris beetle developed in stage $\mathrm{V}$ (scale-1 cm). 
The ycho'i larva Metamasius hemipterus rearing is explained in extenso, as represented in Figure 3 and synthesized in Table 1. Table 1 also summarizes details of the rearing of other two species (Rhynchophorus palmarum and Rhinostomus barbirostris). Those aspects not registered for $M$. hemipterus are described in detail as follows.

Once pre-rearing juvenile individuals of the palm tree (phase III) are felled (Figure 2III), transverse, wedge-shaped incisions are made along the stipe (Figure $3 \mathrm{~A}-\mathrm{B}$ ) in order to promote ovoposition of Metamasius hemipterus. Adult beetles of this species deposit their eggs on exposed tissues in the incisions (Figure $3 \mathrm{C}$ ). For this category we recorded the average number of wedgeshaped incisions made on the stem (3). Regarding periodic diagnosis, the individuals felled are visited weekly and the presence of developing larvae is evaluated. To do this, the stem is gently tapped with the back side of the machete and an acoustic assessment is made according to the sound the grubs emit in response to the disturbance. The sound emitted by the larvae inside the stipe is called ycho oñe endu (larval noise). After a certain time, two months approximately, the larvae are collected ready for consumption (Figure 3D).

Larvae collection is done only once because this species grubs develop in a homogeneous way along the palm stipe. It is carried out from the crown to the base of the stem in all cases, the presence of larvae developed in the stump of the felled plant was also found. When these larvae reach the pupal stage they form cocoons with palm tissue until they become adult insects. Guarani call the cocoon ycho raity, meaning (larva nest) (Figure 3E). It has been observed that transport of larvae to the domestic environment is carried out in a traditional way within the internodes of the takuapi cane, Merostachys claussenii Munro (Poaceae) (Figure 3F), although the use of plastic containers was also noticed (Table 1).

Management practices applied to pindo in stage IV to promote rearing of Rhynchophorus palmarum larvae are showed in Figure 4 and explained in Table 1. Larvae of this species form cocoons with stem tissues (Figure $4 \mathrm{~F}$ ) or, in some cases, dig the soil and return to the stipe after a few days (Figure $4 \mathrm{G}$ ). The Guarani call this phenomenon ycho o'o yvyguy (larvae move under the ground).

Management practices applied to pindo in stage $\mathrm{V}$ to promote rearing of ycho chĩ larva Rhinostomus barbirostris larvae are showed in Figure 5 and detailed in Table 1.

\section{DISCUSSION}

In this work the management of different stages of growth of pindo was found to promote the development of three species of edible beetles. The Guarani of the Atlantic Forest of Argentina decide and control which species of the weevil larva to produce. For this purpose, they select individuals of $S$. romanzoffiana palms in different ontogenic stages. The results highlight a deep understanding of the auto-ecology of the insect species; it also suggests a thorough knowledge of the characteristics of wood morphology along the development of this plant species.

In relation to the classification used by the Guarani to characterize the stage of growth of each individual -sensu Gatsuk et al. 1980-, we found similarities with studies analyzing the population structure of different palm species (Souza et al. 2000, 2003; Svenning 2002; Souza and Martins 2005), as well as in the characterization of the species (Bernacci et al. 2008). 

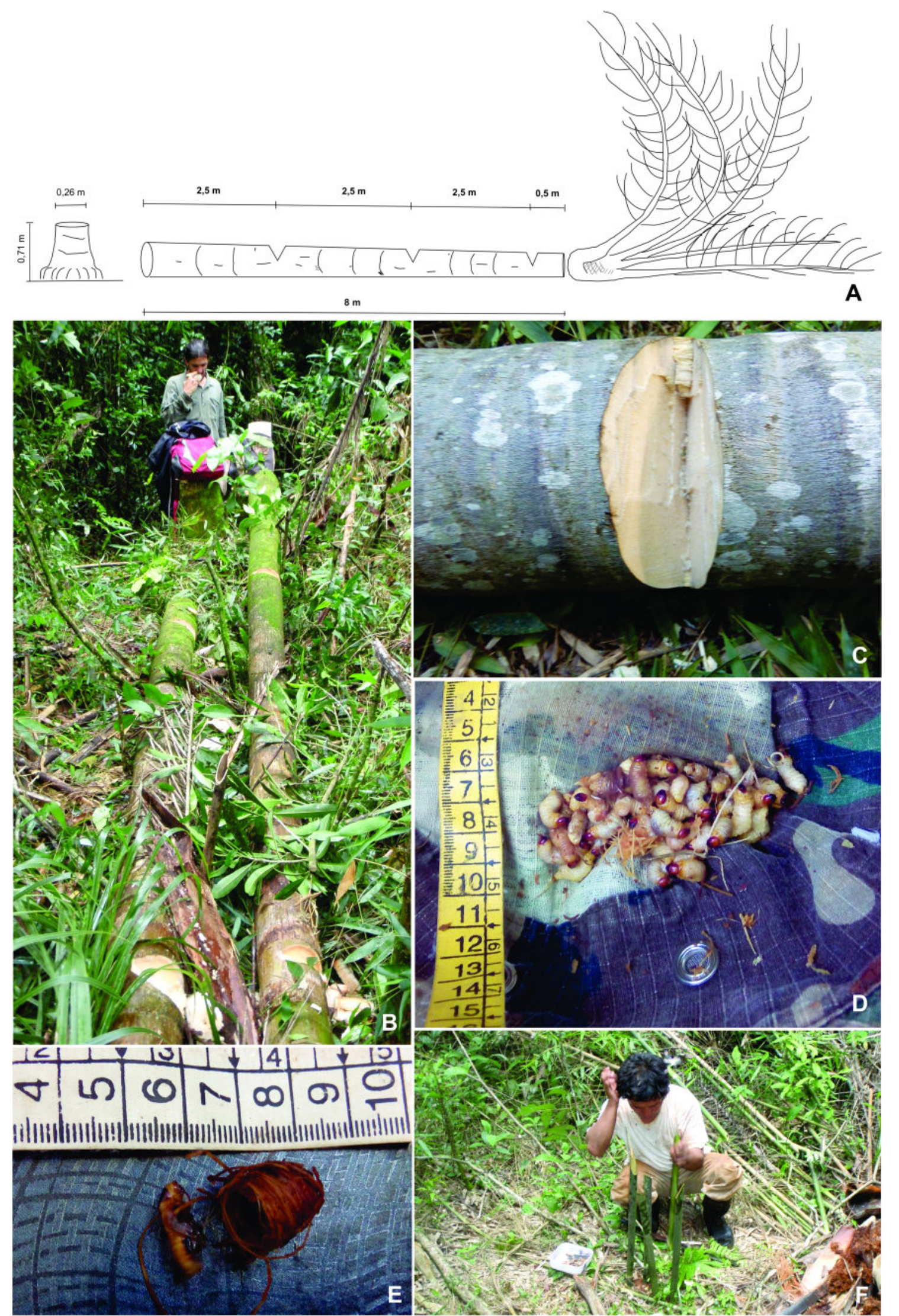

Figure 3. A: Schematic of a felled pindo yky guachu palm tree with three transverse incisions along the stem. B: two specimens of felled pindo yky guachu. C: detail of wedge-shaped incisions made in the stipe. D: collected ycho'i larvae. E: Metamasius hemipterus pupa and cocoon. F: Merostachys claussenii bamboo stem used to transport larvae. 

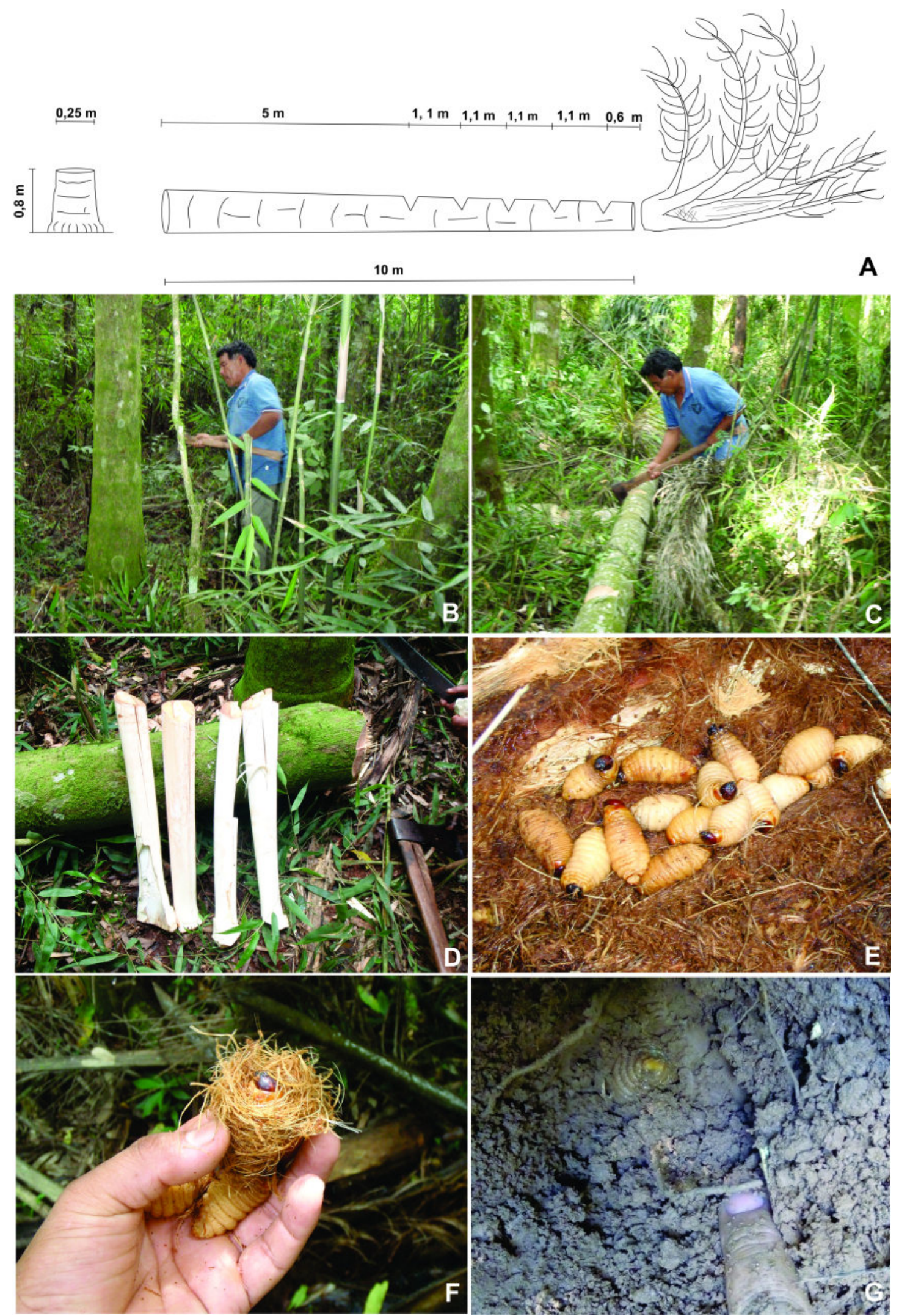

Figure 4. A: Schematic diagram of a pindo pyau palm cut downed with incisions made from the stem middle to its apex. B: Guarani cutting the palm. C: stem incisions. D: heart of the harvested palm. E: harvested ycho pyta larvae Rhynchophorus palmarum. F: larva in cocoon. G: larva inside the soil. 

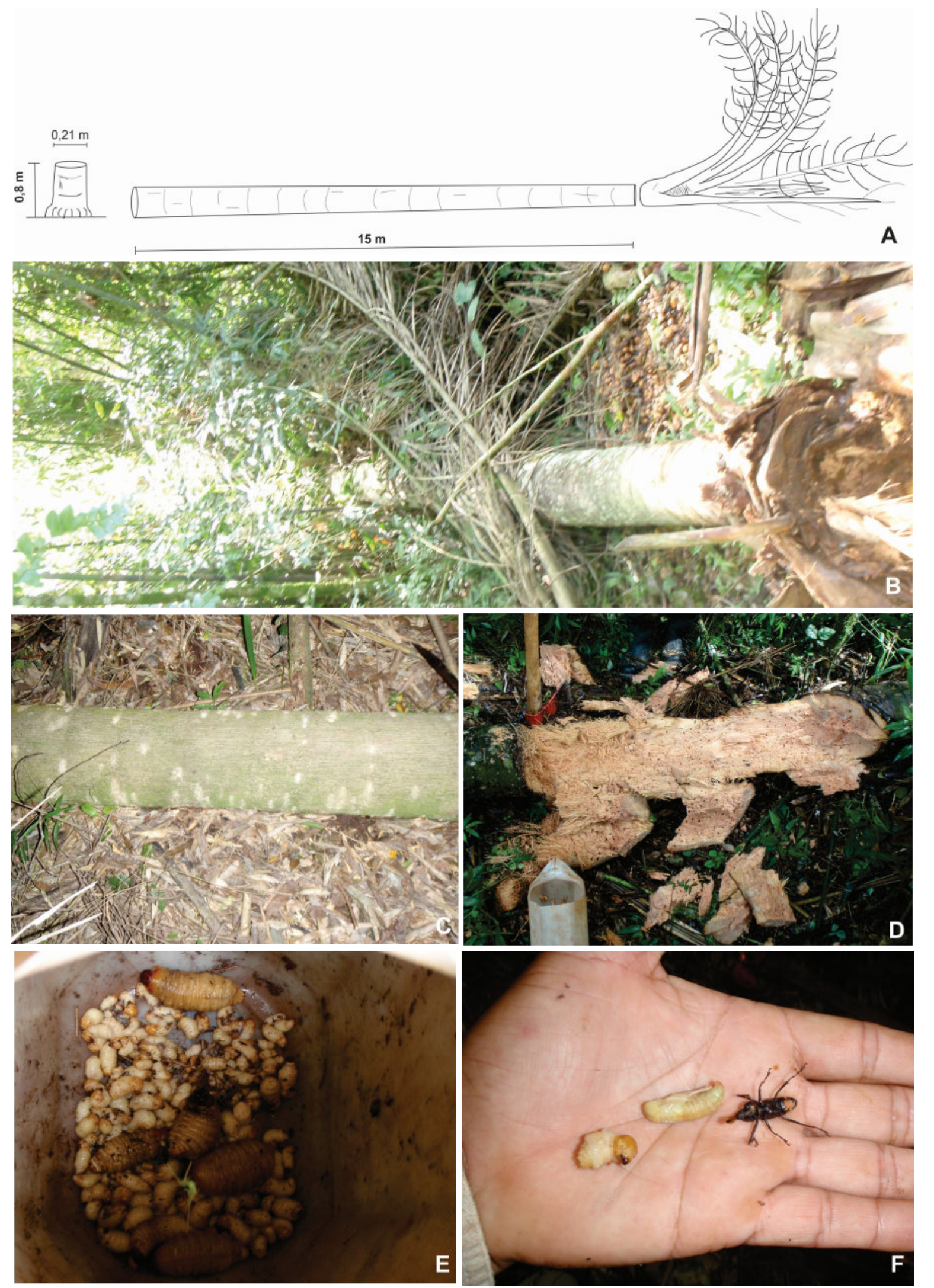

Figure 5. A: Schematic of a felled pindo tuja palm without incisions in the stem. B: a felled specimen pindo tuja. C: presence of sawdust on the stipe cortex. D. collection of ycho chĩ larvae and container used for transport. E: harvested ycho chĩ and ycho pyta larvae. F: Rhinostomus barbirostris larva, pupa and adult (left to right). 
Table 1. Management of the palm tree $S$. romanzoffiana to produce three species of edible larvae of Coleoptera.

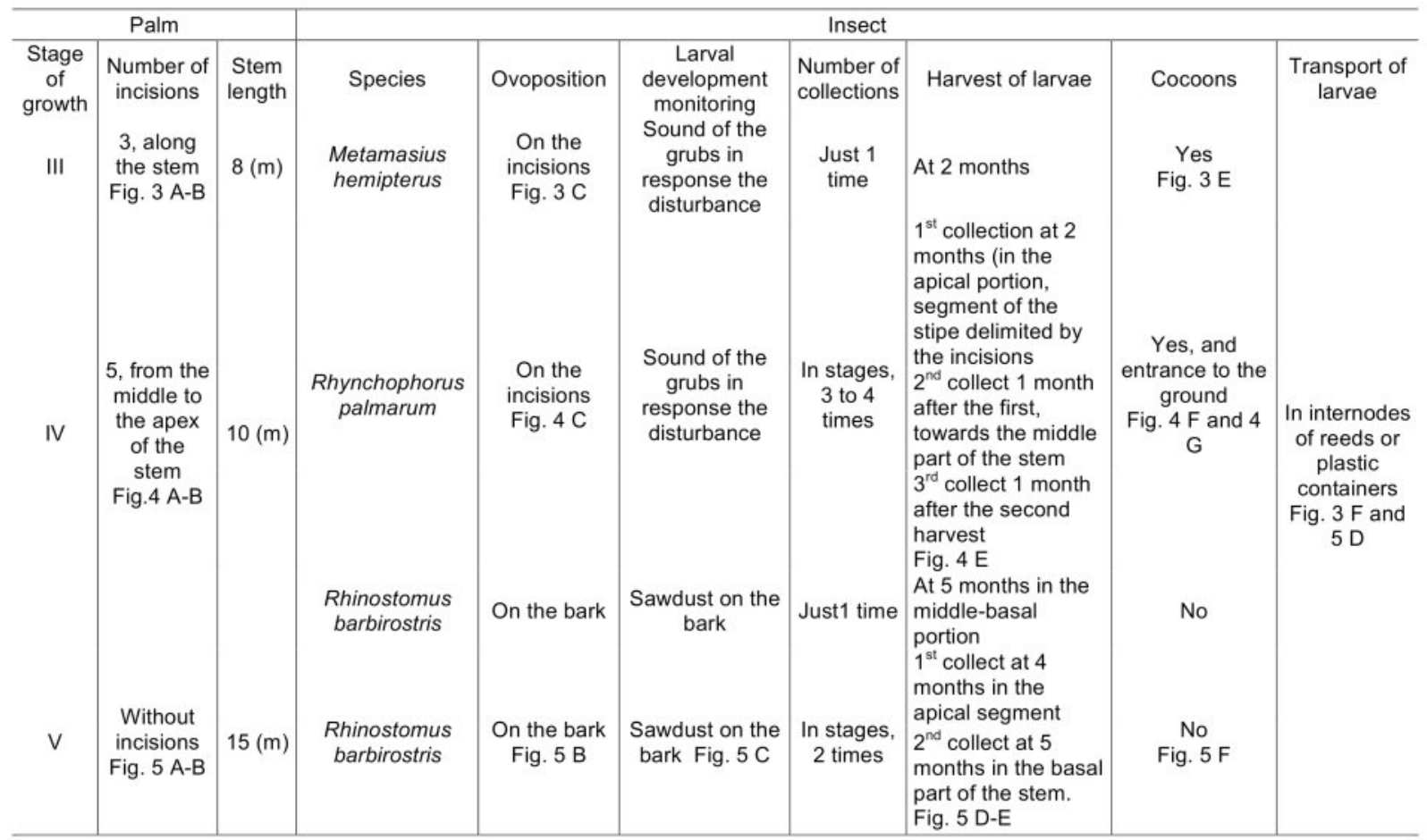

A similar management to that observed in our region for the same palm species has been cited in the Amazon for the Tatuyo Indians (Dufour 1987) and in Paraguay among the Ache Guayaqui (Clastres 1972; Dawson and Gancedo 1977 Hill et al. 1985; Hurtado 1985), in both cases the initial use of the heart, fruits and/or leaves is mentioned. The practice of making incisions in the stipe with the use of old stone axes, nowadays replaced by metal ones, (Mayntzhusen 2009; Townsend 1973) has also been mentioned.

Similar management of other palm species was recorded in other regions. For example, in communities' native to New Guinea, larval rearing of weevils is considered a by-product of the sagu (Metroxylon sagu Rottb. and $M$. rumphii Mart.), species that unlike $S$. romanzoffiana, are multicaules (Ellen 2006; Mercer 1997; Ponzetta and Paoletti 1997; Townsend
1973). In southern Thailand larvae is also bred in sagu palms for commercial purposes, maintaining the traditional method of rearing in the cut plant and artificially, where the rearing is in plastic containers, using the natural substrate (Hanboonsong et al. 2013). In Cameroon, the use of oil and raffia palm (Elaeis guineensis Jacq. and Rhapia sp. Beauv.), respectively was recorded for the same purpose; in both cases the production is for commercial purposes in local markets and according to Dounias (2003) each expert has its specific harvesting tools and techniques.

We registered that palm trees are cut down in spring and summer which agrees with that observed by Dawson and Gancedo (1977) who describe that the best time for this activity is during the heyday of the flowering of certain species. In the same sense, Cadogan (1992) points out the beginning of the lapacho flowering, 
Handroanthus heptaphylus (Vell.) Mattos (Bignoniaceae) "tajy potýpy pytarã jaity" ("we must cut down during the lapacho flowering") as the moment in which palm trees are felled or rearing larvae of Rhynchophorus palmarum; and refers similarly to the flowering of guavira, Campomanesia xanthocarpa (Mart.) O.Berg. (Myrtaceae) for the rearing of Rhinostomus barbirostris "chĩ aviju ombo a anguã guavira potýpy reity va erã guapytangy" (to produce larvae of the hairy snout it is necessary to cut down palm trees when the guavira blooms). According to research carried out by (Cebolla Badie 2013), in the past at times of shortage of resources (which coincides with the flowering of these two tree species), entire communities moved to the palm groves to use the pindo (including the production of weevil larvae) and then returned to their homes at the time of harvesting other crops.

The management of the different stages of growth of the pindo observed in our studied region and the development of different insect species is similar to that described by Choo et al. (2009) for the Joti in Amazonas who manage the palm tree Oenocarpus bacaba Mart. to breed larvae of Rhynchophorus palmarum and Rhinostomus barbirostris. Nevertheless, for the production of Rhynchophorus palmarum in pindo palms in our region, adult individuals in their reproductive stages are selected. Another difference is that, in the case of Metamasius hemipterus only one harvest is made, while that of Rhinostomus barbirostris is made in two stages and that of Rhynchophorus palmarum in three or four.

It was observed that Guarani from the Argentinean Northeast make wedge-shaped incisions in the downed stipe to carry out the rearing of edible larvae of $M$. hemipterus and $R$. palmarum beetles and thus produce edible larvae from their weevils and that adult insects lay their eggs on exposed tissues. Previous studies have shown that these palm weevils require host plants with soft or damaged tissues for oviposition (Giblin-Davis et al. 1994, 1996). It is also reported that male weevils of these insects are attracted by the odor generated by palm tissues fermentation (Morin et al. 1986; Moura et al. 1990, 1991) and that the fermentation of the decomposing material shows its maximum efficiency in 2-3 weeks (Oehlschlager et al. 1993a, b, 2002). In addition to the material from the fermented plant, these insects emit an aggregation of pheromones to attract individuals of both sexes (Giblin-Davis et al. 1996; Rochat et al. 1991; Oehlschlager 2016). In this way, the local observed management suggests a deep knowledge of these insects ecology and of the interactions with the substrates where they oviposited which contributes to explain how larvae of the two desired species ( $M$. hemipterus and $R$. palmarum) are oriented (or attracted) by making incisions in the palm stipes.

With regard to the monitoring of the development of $R$. palmarum larvae in the palm, the use of sound emitted by the larvae as a verification system to determine the degree of occupation of these insects, agrees with data recorded in the literature (Coimbra 1984; Muafor et al. 2014; Van Huis 2003). Similarly, the estimation of the degree of infestation of $R$. barbirostris from the presence of sawdust on the stipe cortex has been observed in other ethnicities (Choo et al. 2009; Dufour 1987).

The collection of larvae in two or more stages (depending on the species of insect and the ontogenetic stage of the palm tree) could be based on the anatomical differences of the palm tissue structure (axial and radial) described for this botanical family 
by Thomas and Franceschi (2013).

On the other hand, in relation to the rearing of Rhinostomus barbirostris, the development of larvae in the senile stages of the palms could be due to a strategy of the species to avoid competition with other insects (Messina and Renwick 1985; Renwick 1989; Choo et al. 2009.According to the descriptions made by (Vaurie 1970), $R$. barbirostris larvae are usually attacked by $R$. palmarum larvae, possibly explaining the development of both species in different portions of the stipe.

\section{CONCLUSION}

The results show that the rearing of edible larvae of the three species of Coleoptera reported here (M. hemipterus, $R$. palmarum and $R$. barbirostris), is not a mere act of gathering. On the contrary, it represents an activity planned months in advance, taking into account several factors, the stage of growth of the palm tree, the seasonal cycle, the lunar phase, diagnostic elements of the forest and techniques of manipulation of the vegetal resource to promote the development of the desired larvae. This set of activities is interpreted as reflecting a holistic understanding by Guarani of the relationship between the host plant, insects and the biota and environment.

\section{ACKNOWLEDGEMENTS}

To the members of the Guarani communities visited for the information provided, to Dra. Analía Lanteri of the Scientific Department of Entomology, Museo de la Plata, Facultad de Ciencias Naturales $y$ Museo, UNLP, Argentina for the identification of the species of insects $R$. palmarum and $R$. barbirostris, to Dr. Bello Ayr, from Rio de Janeiro, Brazil for identifying the adult weevil of $M$. hemipterus. To Drs. Ma. Lelia Pochettino and Monika Kujawska for reviewing the manuscript and for their valuable recommendations. This project was carried out with JJA doctoral fellowship from CONICET.

\section{REFERENCES}

Albuquerque UP, Cunha LVFC, Lucena RFP, Alves RRN (2014) Methods and Techniques in Ethnobiology and Ethnoecology. Springer New York, New York, USA.

Ambrosetti JB (1894) Los indios Cainguá del Alto Paraná. Boletín del Instituto Geográfico Argentino 15: 661-744.

Assis VD and Garlet IJ (2004) Análise sobre as populações guarani contemporâneas: demografia, espacialidade e questões fundiárias. Revista de Indias 64: 35-54.

Balick MJ (1984) Ethnobotany of Palms in the Neotropics. Advances in Economic Botany 1: 923.

Balick MJ and Beck H (1990) Useful palms of world: a synoptic bibliography. Nueva York: Columbia University.

Balslev H (2011) Palm Harvest Impacts in North-Western South America. The Botanical Review 77: 370-380.

Balslev H, Macía MJ, Navarrete H (2015) Cosecha de palmas en el noroeste de Suramérica: Bases científicas para su manejo y conservación. Quito: Pontificia Universidad Católica del Ecuador.

Bernacci LC, Martins FR, Maës dos Santos FA (2008) Estrutura de estádios ontogenéticos em população nativa da palmeira Syagrus romanzoffiana (Cham.) Glassman (Arecaceae). Acta Botánica Brasilera 22: 119130.

Bernal R, Galeano G (2013) Cosechar sin destruir-Aprovechamiento sostenible de palmas colombianas. Facultad de CienciasInstituto de Ciencias Naturales. Universidad Nacional de Colombia, Bogotá.

Bernal R, Torres C, García N, Isaza C, Navarro J, Vallejo MI, Galeano G, Balslev H (2011) Palm Management in South America. The Botanical Review 77: 607-646. 
Bernad HR (2000) Social Research Methods Qualitative and Quantitative Approaches. Sage, University of Florida.

Blacutt-Rivero E, Moraes M, Gruca M, Balslev H (2016) Local knowledge about palms (Arecaceae) among children in Bolivia. Botanical Journal of the Linnean Society 182: 505-516.

Bonomo M, Capeletti LE (2014) Uso prehispánico de las palmeras Syagrus romanzoffiana y Butia yatay en el Nordeste argentino: aportes desde la etnografía y la biometría. Revista del Museo de Antropología 7(2): 227-234.

Borchsenius F, Moraes MR (2006) Palmeras andinas. In: Moraes RM, Øllgaard B, Kvist LP, Borchsenius $\mathrm{F}$, Balslev $\mathrm{H}$ (eds.) Botánica Económica de los Andes Centrales. Herbario Nacional de Bolivia, Universidad Mayor de San Andrés, Plural Editores, La Paz. pp. 412-433

Cabral EL, Castro M (2007) Palmeras Argentinas. Guía para el reconocimiento. Ed. Lola, Buenos Aires.

Cadogan L (1992) Diccionario Mbya-GuaraníCastellano. Biblioteca Paraguaya de Antropología, Asunción 17: 1-211.

Cárdenas M (1989) Manual de Plantas Económicas de Bolivia. Editorial Amigos del Libro. 2 da edición. La Paz, Bolivia.

Cebolla Badie MV (2009) El conocimiento y consumo de himenópteros, coleópteros y lepidópteros en la cultura mbya-guaraní, Misiones, Argentina. Manual de Etnozoología 3: 215-223.

Cebolla Badie MV (2013) Cosmología y naturaleza mbya-guaraní. Tesis de doctorado, Facultad de Geografía e Historia, Universitat de Barcelona.

Cerda H, Martínez R, Briceño N, Pizzoferrato L, Hermoso D, Paoletti M (1999) Cría, análisis nutricional y sensorial del picudo del cocotero Rhynchophorus palmarum (Coleoptera: Curculionidae), insecto de la dieta tradicional indígena Amazónica. Ecotrópicos 12: 25-32.

Cerda H, Martinez R, Briceño N, Pizzoferrato L, Manzi P, Ponzetta MT, Marin O, Paoletti MG (2001) Palm worm (Rhynchophorus palmarum) Traditional food in Amazonas, Venezuelanutritional composition, small scale production and tourist palatability. Ecology of Food and Nutrition, 40: 13-32.
Choo J, Zent EL, Simpson BB (2009) The importance of traditional ecological knowledge for palm-weevil cultivation in the Venezuelan Amazon. Journal of Ethnobiology 29: 113-128.

Clastres P (1972) The Guayaki. In: Bicchieri MG (ed) Hunters and gatherers today. Holt, Rhinehart and Winston, New York, pp. 38-74.

Coimbra CEA, (1984) Estudos de ecologia humana entre os Suruĩ do parque indígena Aripuanã, Rondõnia. 1. O uso de larvas de coleópteros (Bruchidae e Curculionidae) na alimentação. Revista Brasileira de Zoología, 2(2): 35-47.

Costa Neto EM (2004) Implications and applications of folk zootherapy in the state of Bahia, Northeastern Brazil. Sustainable Development 12: 161-174.

Crespo JA (1982) Ecología de la comunidad de mamíferos del Parque Nacional Iguazú, Misiones. Revista MACN Ecología 3: 45-162.

Crivos M, Martínez MR, Pochettino ML (2005) La narrativa acerca del paisaje y del cambio ambiental entre los pobladores del área rural del Municipio de Aristóbulo del Valle (Misiones). Actas del I Congreso Argentino de Inmigración. IV Congreso de Historia de los Pueblos. de la Provincia de Santa Fe.

Dawson G, Gancedo O (1977) La palma pindó (Syagrus romanzoffianum) y su importancia entre los indios Guayaquí. Obra Cent. Mus. La Plata 2: 339-353.

Defoliart GR 1995. Edible insects as minilivestock. Biodiversity and Conservation 4: 306-321.

Delgado C, Couturier G, Mathews P, Mejia K (2008) Producción y comercialización de la larva de Rhynchophorus palmarum (Coleoptera: Dryophtoridae) en la Amazonía peruana. Boletín Sociedad Entomológica Aragonesa 41: 407-412.

Dounias E (2003) L'exploitation méconnu d'une ressource connue: la collecte des larves comestibles de charançons dans les palmiers-raphia au sud du Cameroun. In Les Insectes dans la Tradition Orale. Edited by: Motte-Florac E, Thomas JMC. Paris: Peeters, Etnosciencies, 257-278. 
Dransfield J, Uhl NW, Asmussen CB, Baker WJ, Harley MM, Lewis CE (2008) Genera Palmarum: The Evolution and Classification of Palms. Kew publishing: Royal Botanic Gardens.

Dufour DL (1987) Insects as food: A Case Study from the Northwest Amazon. American Anthropologist 89: 383-397.

Ellen $R$ (2006) Local Knowledge and management of the sago palm (Metroxylon sagu rottboell) diversity in south central Seram, Maluku, eastern Indonesia. Journal of Ethnobiology, 26(2):258-298.

Felipim AP (2001) O Sistema Agrícola Guarani Mbyá e seus cultivares de milho: um estudo de caso na aldeia Guarani da Ilha do Cardoso, município de Cananéia, SP. Dissertação para obtenção do título de mestre em Ciências; Área de concentração: ciencias florestais. Piracicaba: ESALQ.

Gatsuk LE, Smirnova OV, Vorontzova LI, Zaugolnova LB, Zhukova LA (1980) Age states of plants of various growth forms: a review. Journal of Ecology 68: 675-96.

Giblin-Davis RM, Oehlschlager AC, Perez A, Gries G, Gries R, Weissling TJ (1996) Chemical and behavioral ecology of palm weevils (Curculionidae: Rhynchophorinae). Florida Entomologist 79: 153-167.

Giblin-Davis RM, Peña JE, Duncan RE (1994) Lethal pitfall trap for evaluation of semiochemical mediated attraction of Metamasius hemipterus sericeus (Coleoptera, Curculionidae). Florida. Entomologist 77: 247255.

Gragson TI (1992) The Use of Palms by the Pume Indians of Southwestern Venezuela. Principes 36: 133-142.

Guber R (2006) La etnografía, método, campo y reflexividad. Grupo editorial Norma. Buenos Aires, Bogotá.

Hanboonsong Y, Jamjanya T, Durst PB (2013) Six-legged livestock edible insect farming, collecting and marketing in Thailand. Food and Agriculture Organization of the United Nations, Bangkok, Thailand.

Hernández-Pacheco F (1921) Escena pictórica con representaciones de insectos da época paleolítica. Boletín de la Real Sociedad Española de Historia Natural 50: 62-77.
Hill K, Kaplan H, Hawkes K, Hurtado AM (1985) Men's time allocation to Subsistence Work among the Ache of Eastern Paraguay. Human Ecology 13: 29-47.

Hurrell JA, Ulibarri EA, Delucci G, Pochettino ML (2010) Biota Rioplatense XV. Frutas frescas, secas y preservadas. Editorial LOLA. Buenos Aires.

Hurtado AM, Hawkes K, Hill K, Kaplan H (1985) Female subsistence Strategies among Ache Hunter-Gatherers of Eastern Paraguay. Human Ecology doi: 10.1007/BF01531086.

INDEC (2015) Instituto Nacional de Estadística y Censos. Censo Nacional de Población, Hogares y Viviendas 2010: Censo del Bicentenario pueblos originarios, región Nordeste Argentino. 1a ed. Ciudad Autónoma de Buenos Aires.

Jacobsen TR (2003) Endangered Forest, Vanishing Peoples: Biocultural Diversity and Indigenous Knowledge. In: Galindo-Leal G., Gusmao do Camara I. (eds.). Atlantic forest of South America. Biodiversity Status, Threats, and Outlook. Island Press, pp. 381-391

Keller HA (2008) Etnobotánica de comunidades guaraníes de Misiones, Argentina. Valoración de la vegetación como fuente de recursos. Tesis de doctorado en Recursos Naturales, Facultad de Ciencias Agrarias, Universidad Nacional del Nordeste.

Keller HA (2010). Plantas relacionadas con tabúes del ciclo reproductivo de los guaraníes de Misiones, Argentina. Boletín de la Sociedad Argentina de Botánica, 45(1-2):201208.

Keller HA (2014) Consideraciones fitonímicas a partir de dos mitos guaraníes sobre el origen de Arecastrum romanzoffianum (Arecaceae). Suplemento Antropológico de la Universidad Católica de Asunción 49: 287-308.

Keller HA, Prance GT (2008) Plants associated with fish by Guaraníes of Misiones, Argentina. Ethnobotany 20: 1-8.

Macía MJ, Armesilla PJ, Camara-Leret R, Paniagua-Zambrana $\mathrm{N}$, Villalba $\mathrm{S}$, Balslev $\mathrm{H}$, Pardo-de-Santayana M (2011) Palm Uses in Northwestern South America: A Quantitative Review. The Botanical Review 77: 462-570.

Malinowski B (1922) Argonauts of the Western Pacific. Ed. Dutton P. New York. 
Martínez Crovetto RN (1968) La alimentación entre los indios guaraníes de Misiones. Etnobiológica 4: 1-24.

Mayntzhusen F (2009) Los Aché Guayakí. Ed. Junta de estudios históricos de Misiones. Misiones, Argentina.

Messina FJ, Renwick JAA (1985) Mechanism of egg recognition by the cowpea weevil Callosobruchus maculatus. Entomologia Experimentalis et Applicata 37: 241-245.

Mercer CWL (1997) Sustainable production of insects for food and income by New Guinea villagers. Ecology of Food and Nutrition 36: 151157.

Mitsuhashi J (2017) Edible Insects of the World. CRC Press Taylor \& Francis Group. Japan.

Moliniers P, Genes I (2003) Diccionario Guaraní. Diccionario usual de la lengua guaraní. Editorial Visor, Argentina.

Morin JP, Lucchini F, De Araujo JCA, Ferreina JMS, Fraga LS (1986) Rhynchophorus control using traps made from oil palm cubes. Oléagineux 41: 57-62.

Moura JIL, Vilela de Resende ML, De Lima MM, de Q. Santana DL (1991) Taticas para o controle integrado de Rhynchophorus palmarum L. Centro de Pesquisas do Cacau (CEPEC), Bahía, Brazil.

Moura JIL, Vilela de Resende ML, Sgrillo RB, Nascimentl LA, Romano R (1990) Diferentes tipos de armadilhas $e$ iscas no controle Rhynchophorus palmarum L. (Coleoptera: Curculionidae). Agrotropica 2: 165-169.

Muafor FJ, Gall PL, Levang P (2014) Improving rural livelihoods through participative research on the domestication and breeding of the palm weevil larvae (Rhynchophorus phoenicis Fabr.). The African palm weevil project, pp 1-22.

Müller F (1989) Etnografía de los Guaraní del Alto Paraná. Ed. Societatis Verbi Divini. Argentina.

Noblick LR (2017) A revision of the genus Syagrus (Arecaceae). Phytotaxa 294: 1-262.

Noelli FS (2004) La Distribución Geográfica de las evidencias Arqueológicas Guaraní. Revista de Indias 64: 17-34.
Oehlschlager AC (2016) Palm Weevil Pheromones-Discovery and Use. Journal of chemical ecology 42: 617-630.

Oehlschlager AC, Chinchilla CM, Castillo G, Gonzalez L (2002) Control of red ring disease by mass trapping of Rhynchophorus palmarum (Coleoptera: Curculionidae). Florida Entomologist 85: 507-513.

Oehlschlager AC, Chinchilla CM, Gonzalez LM (1993a) Optimization of a pheromone baited trap for the American palm weevil Rhynchophorus palmarum (L.). Palm Oil. Research Institute of Malaysia Int Palm Oil Cong, Kuala Lumpur, Malaysia.

Oehlschlager AC, Chinchilla CM, Jiron LF, Morgan B, Mexon RG (1993b) Development of an effective pheromone based trapping system for the American palm weevil, Rhynchophorus palmarum, in oil palm plantations. J. Econ Entomol 86: 1381-1392.

Onore G (1997) A brief note on the edible insect in Ecuador. Ecology of Food and Nutrition, 36: 277-285.

Paniagua-Zambrana N, Bussmann RW, Macía MJ (2014) El Bosque Sí Tiene Valor: El uso de palmeras en las comunidades campesinas e indígenas de la región de Inambari, Madre de Dios, Perú. Ethnobotany Research and applications 13 (3):001-081.

Paniagua-Zambrana N, Cámara-Leret R, Bussmann RW, Macía MJ (2016) Understanding transmission of traditional knowledge across north-western South America: a cross-cultural study in palms (Arecaceae). Botanical Journal of the Linnean Society 182: 480-504.

Placci LG, Di Bitetti M (2006) Situación ambiental en la Ecorregión del Bosque Atlántico del Alto Paraná (Selva Paranaense). In: Brown A, Martínez Ortíz U, Acerbi M, Corcuera J (eds.). La situación ambiental Argentina 2005. FVS-Argentina. Buenos Aires, pp. 193-210.

Pochettino ML (2015) Botánica económica: las plantas interpretadas según tiempo, espacio y cultura. Sociedad Argentina de Botánica, $1^{\text {a }}$ ed. C. A. Buenos Aires. 
Ponzetta MT, Paoletti MG (1997) Insects as food of the Irian Jaya populations. Ecology of Food and Nutrition 36: 321-346.

Posey DA (1987) Ethnoentomological Survey of Brazilian Indians. Entomol. Gener 12: 191202.

Ramos-Elorduy J (1997) Importance of edible insects in the nutrition and economy of the people of rural areas in Mexico. J. Ecol. Food and Nutr. 36: 347-366.

Ramos-Elorduy J, Pino Moreno JM, Martínez Camacho VH (2009) Edible aquatic Coleoptera of the world with an emphasis on Mexico. Journal of Ethnobiology and Ethnomedicine 5:11.

Reitz R (1974) Palmeiras. Flora Ilustrada Catarinense. Parte 1: as plantas, fascículo: PALM. Herbário "Barbosa Rodrigues," Itajaí, Santa Catarina, Brazil.

Renwick JAA (1989) Chemical ecology of oviposition in phytophagous insects. Cellular and Molecular Life Sciences 45: 223-228.

Rochat D, Malosse C, Lettere M, Ducrot PH, Zagatti P, Renou M, Descoins C (1991) Maleproduced aggregation pheromone of the American palm weevil, Rhynchophorus palmarum (L.) (Coleoptera, Curculionidae): collection, identification, electrophysiological activity, and laboratory bioassay. J Chem Ecol 17: 2127-2141.

Rosso CN, Scarpa GF (2012) Identificaciones botánicas de las plantas empleadas entre los Mocovíes en la reducción San Javier durante el Siglo XVIII a partir de la obra de Florián Paucke S J. In: Arenas P (ed) Etnobotánica en zonas áridas y semiáridas del cono sur de Sudamérica. CEFYBO-CONICET, Buenos Aires, pp: 45- 70.

Schmitz PI (1991) Migrantes da Amâzonia: A Tradição Tupiguaraní. Kern AA (ed) Arqueologia pré-histórica do Rio Grande do Sul, Mercado Alberto, Porto Alegre, pp. 295-330.
Souza AF, Martins FR (2005) Spatial variation and dynamics of flooding, canopy openness, and structure in a Neotropical swamp forest. Plant Ecology 180: 161-173.

Souza AF, Martins FR, Bernacci LC (2003) Clonal growth and reproductive strategies of the understory tropical palm Geonoma brevispatha: an ontogenetic approach. Canadian Journal of Botany 81: 101-112.

Souza AF, Martins FR, Silva Matos DM (2000) Detecting ontogenetic stages of the palm Attalea humilis in fragments of the Brazilian Atlantic forest. Canadian Journal of Botany 78 : 1227-1237.

Svenning JC (2002) Crown illumination limits the population growth rate of a neotropical understorey palm (Geonoma macrostachys, Arecaceae). Plant Ecology 159: 185-199.

Thomas R, De Franceschi D (2013) Palm stem anatomy and computer-aided identification. The Coryphoideae (Arecaceae). American Journal of Botany 100: 289-313.

Townsend PK (1974) Sago production in a New Guinea Economy. Human Ecology 2: 217-236.

Van Huis A (2003) Insect as food in subSaharan Africa. Insect and Science and its Application, 23(3):163-185.

Van Itterbeeck J,Van Huis A (2012) Environmental manipulation for edible insect procurement: a historical perspective. Journal of Ethnobiology and Ethnomedicine 8: 3.

Vaurie P (1970) Weevils of the tribe Sipalini (Coleoptera, Curculionidae, Rhynchophorinae) Part 1. The genera Rhinostomus and Yaccaborus. American Museum Novitates, 2419:1-57.

Received: 11 September 2017

Accepted: 16 November 2017

Published: 5 December 2018 